\title{
Integrated Effect of Host Plant Resistance and Fungicidal Seed Treatment on Rice Blast Control in Brazil
}

\author{
M. C. Filippi and A. S. Prabhu, National Rice and Bean Research Center (EMBRAPA/CNPAF), C.P. 179, 74001- \\ 970 Goiânia, GO, Brazil
}

\begin{abstract}
Filippi, M. C., and Prabhu, A. S. 1997. Integrated effect of host plant resistance and fungicidal seed treatment on rice blast control in Brazil. Plant Dis. 81:351-355.

A field experiment was conducted in two successive years at Goiânia, GO, Brazil, to study the effect of seed treatment with pyroquilon fungicide ( $4.0 \mathrm{~g}$ a.i. per $\mathrm{kg}$ of seed) on rice blast in cultivars that differed in their level of resistance. Leaf and panicle blast progress was monitored in the newly released, early maturing upland rice cultivar Guarani and the advanced line CNA 4136, and compared with disease progress in the susceptible commercial cultivars IAC 165 and IAC 25 in plots with treated and untreated seed. Seed treatment suppressed leaf blast until 62 and 47 days after seeding in 1987 and 1988, respectively, when averaged across cultivars. The slow blasting nature of Guarani and CNA 4136 increased the level of disease control when environmental conditions favored blast development in 1988. Under high disease pressure the correlation between leaf blast and panicle blast severity in the field plots was negative $(r=-0.5, P$ $=0.01)$. Leaf blast severity at 47 days after seeding was negatively correlated to grain yield $(r=$ $-0.709, P=0.001)$. Guarani exhibited an increase in grain yield over the untreated control of $28 \%$, corresponding to $826 \mathrm{~kg} / \mathrm{ha}$.
\end{abstract}

Additional keyword: Pyricularia grisea

Rice blast caused by Pyricularia grisea (Cooke) Sacc. (= Magnaporthe grisea $(\mathrm{T}$. T. Herbert) Yaegashi \& Udagawa) causes significant yield losses in many rice growing countries $(9,15,18,21)$. In Brazil, it is one of the major yield constraints on yield in both irrigated and upland ecosystems. Both leaf and panicle blast account for significant yield losses in upland rice cultivars, depending upon the degree of cultivar susceptibility $(22,23)$.

There has been a distinct change in the pattern of agriculture in west-central Brazil. In the past, upland rice was grown in newly opened savannas to minimize the cost of planting pasture. Now, rice is grown in rotation with soybean or corn, using high input technology, mainly in upland rice regions where environmental conditions are favorable. Mechanized upland rice cultivation in extensive contiguous areas, prolonged periods of dew, cultural practices including high rates of nitrogen application, closer plant spacing, and late planting are some of the factors that have increased the importance of rice blast (25).

Corresponding author: M. C. Filippi

E-mail: cristina@cnpafembrapa.br

Accepted for publication 19 December 1996.

Publication no. D-1997-0224-05R

This article is in the public domain and not copyrightable. It may be freely reprinted with customary crediting of the source. The American Phytopathological Society, 1997.
In the past two decades, research at both the national and state levels has been directed toward breeding for blast resistant cultivars. A large number of upland rice cultivars with different degrees of resistance have been developed. "Guarani" is one of the improved, early maturing cultivars possessing a relatively high degree of partial resistance. The resistance in this cultivar is not complete and yield losses occur when weather conditions are conducive to disease development. An important goal of current research is integrated blast disease management with slow blasting resistance as a major tool along with other cultural and chemical control practices.

Fungicide seed treatment is one of the low cost control measures available in Brazil for blast management. A number of fungicides have been reported to reduce the seed-borne inoculum in different parts of the world, including Brazil $(1,21,24)$. Among the fungicides registered for seed treatment against $P$. grisea, only carboxin and thiabendazole are systemic in nature (24). Although these fungicides have been shown to be effective for blast control, their residual activity is low (4). Suppression of leaf blast control by treating seed with pyroquilon, a newly registered systemic fungicide, has been demonstrated in previous studies conducted in Brazil (24) and elsewhere $(1,4,10,17,20,29)$. Pyroquilon seed treatment has suppressed leaf blast development in cultivars possessing moderate levels of host plant resistance (24). Significant differences in cultivar response to leaf blast after seed treatment with the systemic fungicide tricyclazole have been reported (2). Leaf blast control was improved by combining slow blasting resistance with fungicidal seed treatment (2). The efficacy of pyroquilon seed treatment in protecting a crop for longer periods with no known non-target effects on associated microflora justifies further studies of its use as one of the components in rice blast management. There is very little information on the effect of leaf blast control on panicle blast and yield in upland rice. In the present paper, the combined effect of cultivar resistance and fungicide seed treatment on leaf blast control and its influence on panicle blast and grain yield were investigated.

\section{MATERIALS AND METHODS}

Field plots and treatments. A field experiment was conducted at the National Rice and Bean Research Center (CNPAF/ EMBRAPA), Goiânia, GO, during 1986 to 1987 and 1987 to 1988 . The experimental design was a split-plot with three replications. Main plot treatments consisted of seeds treated with the fungicide pyroquilon and untreated seeds (control). The subplots included four early maturing (115 days) cultivars/lines (CNA 4136, Guarani, IAC 25 , and IAC 165$)$. Subplots $(15 \times 15 \mathrm{~m})$ of each of the cultivars, consisting of 30 rows, $15.0 \mathrm{~m}$ long with $0.50 \mathrm{~m}$ between the rows, were established in the form of a square. Four rows with a mixture of susceptible cultivars (IAC 47, IAC 165, and IRAT 112) were seeded on all four sides of the main plot as spreaders under natural field infection. Main plots were separated by three buffer rows of the highly blast resistant cultivar Três Marias to reduce interplot interference. Both spreader and buffer rows were established 30 days before planting the experiment. Plots were fertilized at planting with (per ha) $200 \mathrm{~kg}$ (5-30$15+\mathrm{Zn}$ ) of NPK, $50 \mathrm{~kg}$ of $\mathrm{N}$ in the form of ammonium sulfate, and $20 \mathrm{~kg}$ of zinc sulfate. Seeds were sown at the rate of 40 kg/ha on 3 December 1986 and 26 November 1987.

Seeds were treated with pyroquilon (Fongorene 50WP), as a slurry with $10 \mathrm{ml}$ of water per $\mathrm{kg}$ of seed. The fungicide (4.0 $\mathrm{g}$ a.i. per $\mathrm{kg}$ of seed) was mixed with $500 \mathrm{~g}$ lots of seed in a 2-liter, round-bottomed flask. The flask was kept at a $45^{\circ}$ angle and hand shaken for 10 to 15 min until seeds were uniformly coated. 
Disease assessment. Leaf blast severity (LBS) was assessed on four or five fully expanded leaves of 20 main tillers of randomly selected plants in the four central rows of each subplot. In the 1986 to 1987 experiment, serial observations were made based on expanded lesions per leaf at 3-day intervals starting from 19 January at 47 , $50,53,56,59$, and 62 days after seeding (DAS). Disease assessment terminated when lesions started coalescing on the upper leaves. In the 1987 to 1988 experiment, leaf blast evaluations were made beginning on 31 December at $35,38,41,44$, and 47 DAS, using the Horsfall-Barratt grading system (11). The ratings (1 to 12) were converted to percent disease severity values with the conversion table containing intraclass interpolation of rating scores (6).

For panicle blast evaluation, four halfmeter sections of row, one each in four central rows of the plot, were demarcated with wooden stakes. All panicles in the four half-meter observational units were assessed beginning 10 days after 5\% panicle emergence. Panicle blast severity (PBS) was measured with a five-grade scale of $0,5,25,50,75$, and $100 \%$ infected

Table 1. Effect of seed treatment with pyroquilon on leaf blast and panicle blast

\begin{tabular}{|c|c|c|c|c|}
\hline \multirow[b]{2}{*}{ Treatment } & \multicolumn{2}{|c|}{ eaf blast ${ }^{\mathbf{w}}$} & \multicolumn{2}{|r|}{ blast $^{x}$} \\
\hline & & & & \\
\hline & & & & \\
\hline & & & & \\
\hline \multicolumn{5}{|c|}{$\begin{array}{l}\text { leaf and percent leaf blast } \\
\text { fter seeding (DAS) in } 1987 \\
\text { vely. Data were transformed } \\
\text { to analysis. Means were } \\
\text { everities across cultivars. } \\
\text { t severity at } 98 \text { and } 97 \text { DAS } \\
\text { respectively. } \\
\text { with pyroquilon at the rate } \\
\text { of seed. } \\
\text { y the same letter in a col- } \\
\text { r significantly according to } \\
0.05 \text { probability level. }\end{array}$} \\
\hline
\end{tabular}

Table 2. Mean leaf blast and panicle blast of fungicide-treated and untreated seed plots in four rice cultivars

\begin{tabular}{lcclll}
\hline & \multicolumn{2}{c}{ Leaf blast $^{\mathrm{x}}$} & & \multicolumn{2}{c}{ Panicle blast $^{\mathbf{y}}$} \\
\cline { 2 - 3 } \cline { 5 - 6 } Cultivar & $\mathbf{1 9 8 7}$ & $\mathbf{1 9 8 8}$ & & $\mathbf{1 9 8 7}$ & $\mathbf{1 9 8 8}$ \\
\hline IAC 165 & $1.9 \mathrm{a}^{\mathrm{z}}$ & $26.2 \mathrm{a}$ & & $35.3 \mathrm{a}$ & $20.1 \mathrm{a}$ \\
IAC 25 & $1.8 \mathrm{a}$ & $30.6 \mathrm{a}$ & & $18.8 \mathrm{bc}$ & $23.2 \mathrm{a}$ \\
CNA 4136 & $0.1 \mathrm{~b}$ & $19.3 \mathrm{bc}$ & & $31.6 \mathrm{ab}$ & $20.0 \mathrm{a}$ \\
Guarani & $0.7 \mathrm{~b}$ & $12.5 \mathrm{c}$ & & $6.4 \mathrm{c}$ & $15.7 \mathrm{a}$ \\
\hline
\end{tabular}

${ }^{x}$ Lesions per leaf and percent leaf area affected 62 and 47 days after seeding (DAS) in 1987 and 1988, respectively. Data were transformed by arcsin prior to analysis. Means were based on averages of untreated and pyroquilontreated plots at the rate of $4.0 \mathrm{~g}$ a.i. per $\mathrm{kg}$ of seed.

y Panicle blast severity (\%) at 98 and 102 DAS in 1987 and 1988, respectively.

${ }^{\mathrm{z}}$ Means followed by the same letter do not differ significantly according to Tukey's test at the 0.05 probability level. spikelets per panicle. The mean percentage of panicles with blast was calculated based on approximately 200 panicles per subplot. Incidence of leaf scald caused by Microdochium oryzae (Hashioka \& Yokogi) Samuels \& I. C. Hallet (syn. Rhynchosporium oryzae Hashioka \& Yokogi) occurred in negligible proportions at the boot stage in the 1987 to 1988 experiment. No other diseases were observed in either year.

Yield assessment. Dry matter production was assessed in the 1987 to 1988 experiment. Plant dry weight per $\mathrm{m}^{2}$ was based on plants harvested from $0.5-\mathrm{m}$ sections of the four central rows. The plant material was oven dried at $70^{\circ} \mathrm{C}$ until constant weight was obtained. The four central 3 -m rows $\left(2 \times 3 \mathrm{~m}^{2}\right)$ of each subplot were harvested and grain yield $(\mathrm{kg} / \mathrm{ha})$ adjusted to $13 \%$ moisture. The experiments were harvested on 1 April 1987 and 22 March 1988 , and were identified by the year they were harvested.

Data analysis. Analysis of variance (ANOVA) was used to determine the effect of seed treatment and cultivar resistance on leaf and panicle blast at each assessment date, and yield by year. The data on lesion number and leaf and panicle blast seventies were transformed to arcsine to reduce the heterogeneity of variance before analysis. Means were compared for significance, using Tukey's test at the $5 \%$ probability level. The apparent infection rate was used as a criterion for determining cultivar resistance. Percentages of disease severity were converted to proportions and the infection rate was calculated by linear regression, after the transformation of disease proportions to logits $\left(\log _{\mathrm{e}} x / 1-x\right)$ according to Van der Plank (28). Slopes of disease progress curves were compared for significance between the treatments with Student's $t$ test (27). ANOVA was conducted for grain yield data, across years.

\section{RESULTS}

Seed treatment and cultivar differences were significant in relation to leaf blast and grain yield in both years of the study. A significant difference for panicle blast was observed only in 1988. Because there was no significant cultivar $\times$ fungicide seed treatment interaction for leaf and panicle blast, the results are presented in the form of overall treatment effects as averages of

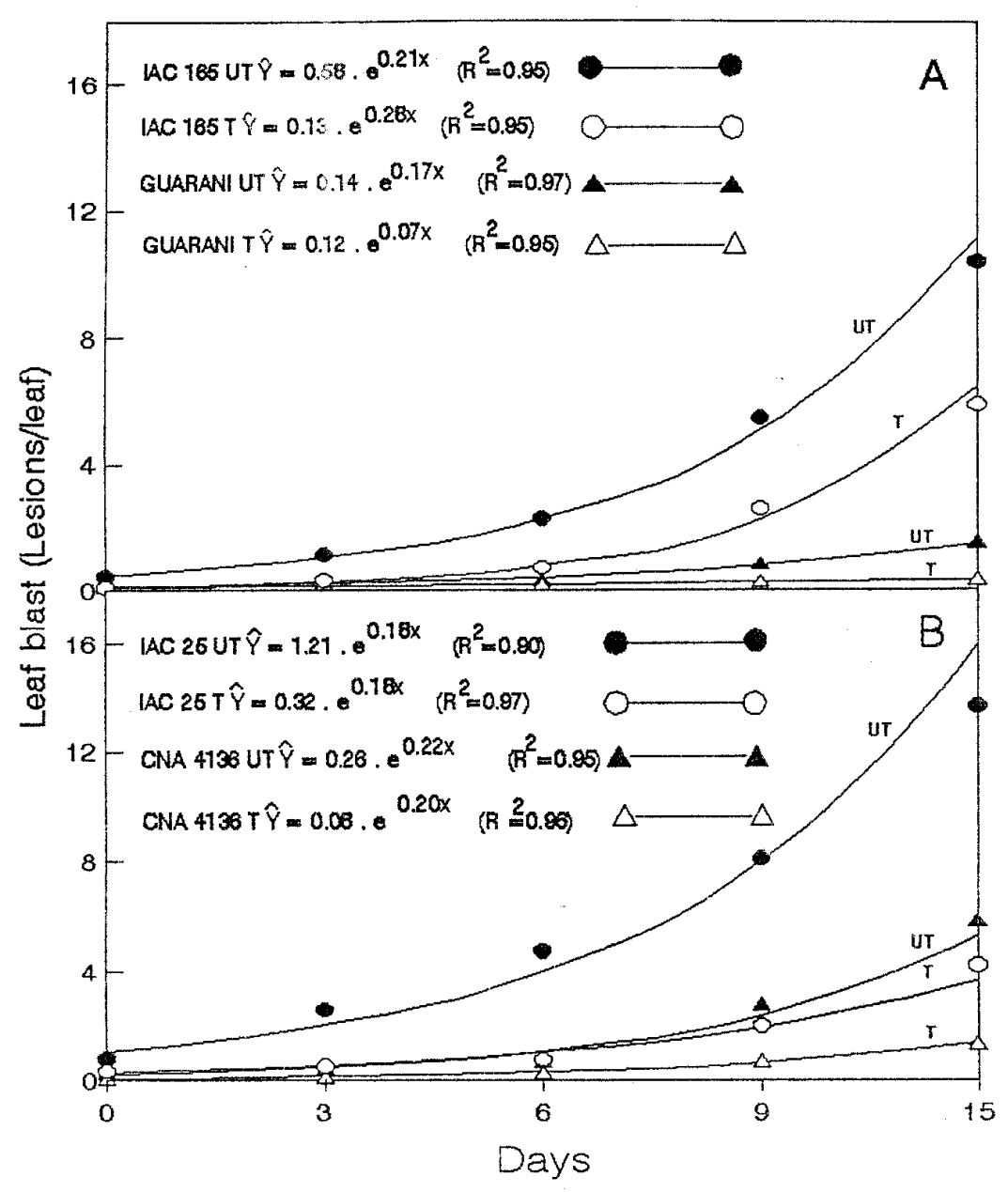

Fig. 1. Disease progress curves of cumulative expanded leaf lesions with time for fungicide-treated and untreated seed plots (1987). (A) Cultivars IAC 165 and Guarani. (B) Cultivar IAC 25 and line CNA 4136. Day $0=47$ days after seeding. UT $=$ seed untreated. $\mathrm{T}=$ seed treated with pyroquilon (4.0 $\mathrm{g}$ a.i. per $\mathrm{kg}$ of seed). $R^{2}=$ coefficient of determination. 
four test cultivars to study the fungicide response (Table 1) and cultivar differences, combining the data of fungicide-treated and untreated plots (Table 2).

Leaf blast. Expanded sporulating leaf blast lesions were first observed at 40 DAS in 1987. Fungicide seed treatment significantly suppressed lesion numbers per leaf, by $52 \%$ until 62 DAS (Table 1). In 1988, the first appearance of leaf blast was noted at 25 DAS and lesions started coalescing 35 DAS. Seed treatment reduced the blast affected leaf area by $44 \%$ in treated plots at 47 DAS. The increase in cumulative lesion number in both treated and untreated plots was exponential for all four cultivars (Fig. 1). The difference between treated and untreated plots was more evident with the susceptible cultivars IAC 165 and IAC 25 than with Guarani and line CNA 4136. In 1988 , the slopes of leaf blast disease progress of untreated and fungicide-treated plots were significantly different for IAC $165(t=3.31, P=0.02)$ and IAC $25(t=$ $3.90, P=0.01)$, and nonsignificant for Guarani and CNA 4136 (Fig. 2). Considering the averages for treated and untreated plots, Guarani and CNA 4136 had significantly fewer lesions per leaf and a lower percent leaf area affected, compared with IAC 165 and IAC 25 in both years (Table 2). There was a significant increase in dry matter production in response to treatment in 1988. Untreated and fungicide-treated plots had 3,190 and 3,920 kg of dry matter per ha, respectively.

Panicle blast. While there was no difference between treated and untreated plots for PBS in 1987, PBS increased by $148 \%$ in response to seed treatment in 1988 (Table 1). In 1987, PBS was significantly lower in Guarani than in the susceptible cultivar IAC 165 when average disease severities of fungicide-treated and untreated plots were considered. CNA 4136 exhibited a relatively high mean PBS. This did not correspond with the low mean LBS exhibited by this cultivar (Table 2). In 1988, differences in mean PBS were not statistically significant. The infection rate was lowest in 1987 for Guarani when average panicle blast progress of untreated and fungicide-treated plots was plotted over time. The apparent infection rates, in decreasing order, were $0.27 \pm 0.11$, $0.20 \pm 0.03,0.19 \pm 0.03$, and $0.15 \pm 0.03$, for CNA 4136, IAC165, IAC25, and Guarani, respectively.

Simple correlation coefficients between LBS, PBS, and grain yield are shown in Table 3. The correlations between serial observations of LBS made from 35 to 47 DAS and PBS at 97 and 102 DAS were negative and significant. The correlation was highest between LBS at 38 DAS and PBS at 97 DAS $(r=-0.51, P=0.01)$.

Grain yield. The combined analysis of grain yield data showed a significant cultivar $\times$ seed treatment interaction, indicating the seed treatment effect was different among cultivars.
Fungicide seed treatment significantly increased grain yield, by $26.8 \%$ when averaged across cultivars. The variation in grain yield was explained only by leaf blast. The correlation between LBS at 47 DAS and grain yield was negative and highly significant $(r=-0.70, P=0.001)$ in 1988 (Table 3 ). The dry matter production was positively correlated with grain yield ( $r=0.77, P=0.0001)$. Guarani exhibited a significant increase in grain yield over the untreated control, by $28 \%$, corresponding to $826 \mathrm{~kg} / \mathrm{ha}$ (Table 4$)$.

\section{DISCUSSION}

Seed treatment with pyroquilon was highly effective in suppressing leaf blast in these experiments. In 1987, the overall level of disease severity was relatively low with the delay in the onset of expanded sporulating lesions up to 40 DAS. Lesions started coalescing at 62 DAS on lower leaves and further disease progress terminated on upper leaves. Significant differences in lesion number were evident, being lower in fungicide-treated plots. Under usual environmental conditions prevailing in Goiânia, leaf blast first makes its appearance at 25 to 30 DAS and advances rapidly to upper leaves. Leaf blast attains its peak between 40 to 50 DAS and starts declining at 60 DAS due to age-mediated resistance of leaves. The increase of resistance of rice with increased plant age to

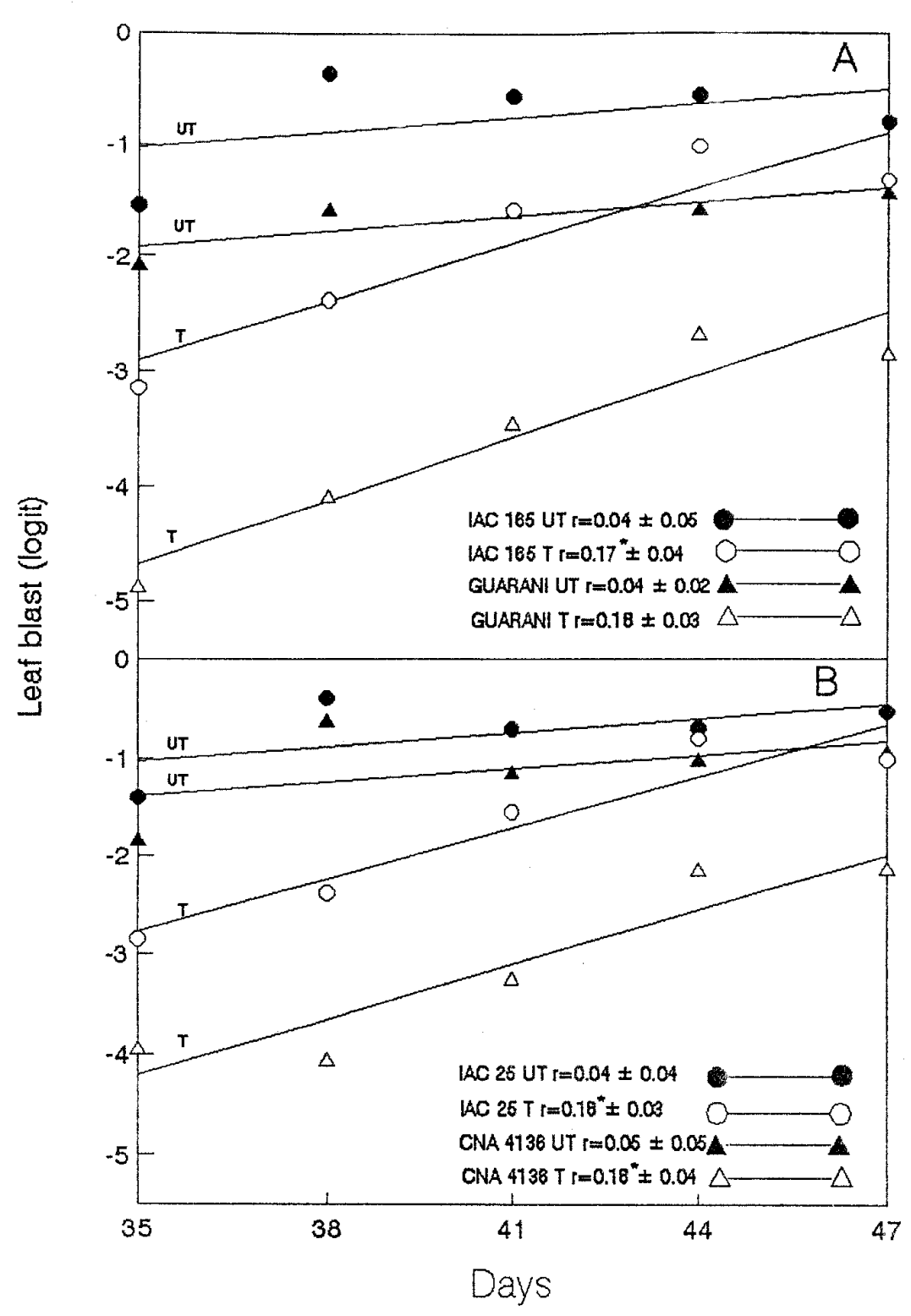

Fig. 2. Progress of leaf blast over time in untreated and fungicide-treated seed plots of four rice cultivars (1988). (A) Cultivars IAC 165 and Guarani. (B) Cultivar IAC 25 and line CNA 4136. UT $=$ seed untreated. $\mathrm{T}=$ seed treated with pyroquilon $(4.0 \mathrm{~g}$ a.i. per $\mathrm{kg}$ of seed). Leaf blast severities transformed to logits of $x, r=$ apparent infection rate \pm standard error. Asterisk following $r$ values indicates slopes of progress curves of fungicide-treated and untreated seed were significantly different according to Student's $t$ test at the 0.05 probability level. 
leaf blast has been reported to be a common phenomenon by several investigators $(3,5,7,8,12,13,16,26)$. Thus, leaf blast control seems to be unimportant after the plant attains the resistant phase during its later growth. The maximum benefit that can be expected of seed treatment is protection up to 60 DAS in upland rice-growing conditions. In 1988, disease pressure was unusually high, possibly due to the contribution of primary inoculum by infected fallen debris from the previous experiment, followed by favorable weather conditions. The residual activity of pyroquilon protected the plants, starting from 38 DAS, even under heavy disease pressure. Similar results were obtained in previous studies conducted in blast nurseries with other cultivars under both low and high disease pressure in Brazil (24) and other countries $(4,10,17,20,29)$.

In large farm holdings in west-central Brazil, rice is successively planted, starting in October with the onset of rains until the end of January. In late-sown plantings in December and January, the blast epidemics start much earlier, leading to total death of many plants (25). Upland rice is classified into favorable and unfavorable ecosystems, based on the rainfall distribution in the redense planting, and heavy nitrogen fertilization enhance disease outbreaks. Under these conditions, pyroquilon seed treatment can provide desirable control of leaf blast, and the present results are in agreement with earlier tests conducted in uniform blast nurseries (24). In an unfavorable upland rice ecosystem, blast is more severe due to predisposition of plants to blast caused by intermittent drought periods (25). Cultivar resistance assumes a major role in reducing yield losses, as the combined effect of blast and drought is more severe in susceptible cultivars. The disease gion where it is cultivated. In a favorable upland rice ecosystem an adequate rainfall,

progress curves showed cultivar differences in relation to leaf blast control with seed treatment. The slow blasting nature of the resistance $(2,19)$, considered here as synonymous with rate reducing resistance without any genetic connotation, was evident in fungicide-treated plots of the improved cultivar Guarani and the line CNA 4136 , both under conditions unfavorable and favorable for disease development in 1987 and 1988, respectively. When disease pressure was low, the differences in lesion number, for treated and untreated plots, were more evident in commercial cultivars IAC 165 and IAC 25 than in Guarani and line CNA 4136. However, when disease pressure was high the control response was not significant in Guarani, suggesting the importance of host plant resistance. Similar results on the combined effect of slow blasting resistance and seed treatment with tricyclazole were obtained under upland conditions in Colombia (2).

Conidia produced by leaf lesions are known to contribute to panicle blast incidence (13). In 1987, the correlation between LBS and PBS was not significant, possibly due to low disease pressure. However, under high disease pressure in 1988 , the correlation between LBS and PBS was negative and significant. Heavy leaf blast incidence affected crop growth and productive tillers, resulting in small panicles with few grains and low panicle blast incidence. Correlation between rice yields and the number of productive tillers is generally very high (15). This has also been the common observation in upland rice farms in which leaf blast causes partial or total destruction of the crop at the vegetative phase $(24,25)$. The fungicide-treated plots suffered less from leaf blast and produced a luxurious crop with delayed senescence, resulting in relatively greater panicle blast severities. Dry matter was significantly higher in fungicide-treated plots than in

Table 3. Simple correlation coefficients (r) between leaf blast severity (LBS) and panicle blast severity (PBS), and dry matter and yield in subplots $(1988)^{\mathrm{x}}$

\begin{tabular}{|c|c|c|c|c|}
\hline \multirow[b]{2}{*}{ Variable } & \multicolumn{2}{|c|}{ PBS } & \multirow[b]{2}{*}{ Dry matter } & \multirow[b]{2}{*}{ Grain yield } \\
\hline & 97 DAS $^{y}$ & 102 DAS $^{y}$ & & \\
\hline \multicolumn{5}{|l|}{$\overline{L B S}$} \\
\hline $35 \mathrm{DAS}$ & $\begin{array}{l}-0.482 \\
(0.017) \mathrm{z}\end{array}$ & $\begin{array}{c}-0.433 \\
(0.034)\end{array}$ & $\begin{array}{l}-0.667 \\
(0.0004)\end{array}$ & $\begin{array}{c}-0.487 \\
(0.015)\end{array}$ \\
\hline $38 \mathrm{DAS}$ & $\begin{array}{c}-0.507 \\
(0.011)\end{array}$ & $\begin{array}{c}-0.486 \\
(0.016)\end{array}$ & $\begin{array}{l}-0.731 \\
(0.0001)\end{array}$ & $\begin{array}{c}-0.521 \\
(0.009)\end{array}$ \\
\hline $41 \mathrm{DAS}$ & $\begin{array}{c}-0.438 \\
(0.032)\end{array}$ & $\begin{array}{c}-0.404 \\
(0.040)\end{array}$ & $\begin{array}{l}-0.704 \\
(0.0001)\end{array}$ & $\begin{array}{c}-0.611 \\
(0.001)\end{array}$ \\
\hline 47 DAS & $\begin{array}{c}-0.202 \\
(0.342)\end{array}$ & $\begin{array}{c}-0.131 \\
(0.539)\end{array}$ & $\begin{array}{c}-0.729 \\
(0.001)\end{array}$ & $\begin{array}{c}-0.709 \\
(0.001)\end{array}$ \\
\hline \multicolumn{5}{|l|}{ PBS } \\
\hline 97 DAS & $\ldots$ & $\begin{array}{c}0.929 \\
(0.0001)\end{array}$ & $\ldots$ & $\begin{array}{c}-0.014 \\
(0.944)\end{array}$ \\
\hline 102 DAS & $\ldots$ & $\ldots$ & $\ldots$ & $\begin{array}{c}-0.083 \\
(0.696)\end{array}$ \\
\hline Dry matter & $\ldots$ & $\ldots$ & $\ldots$ & $\begin{array}{c}0.777 \\
(0.0001)\end{array}$ \\
\hline
\end{tabular}

\footnotetext{
${ }^{\mathrm{x}}$ Number of observations in the analysis $(\mathrm{n})=24$

y Days after seeding.

${ }^{\mathrm{z}}$ Values in parentheses indicate the probability level.
}

untreated plots. Leaf blast severities in subplots explained the variation in dry matter production $(r=-0.73, P=0.0001)$. In earlier studies, leaf blast affected dry matter yield and plant height in upland rice (22). Further studies are required to elucidate the level of LBS that reduces or increases PBS.

In the present study, PBS did not attain levels adequate to affect the grain yield. Even though the yields of fungicide-treated plots were higher than those of untreated plots of all cultivars, the differences were statistically significant only for Guarani. The significant yield increase in Guarani may be attributed to the combined effect of slow leaf and panicle blast resistance and fungicide seed treatment. These results indicated the necessity to utilize cultivars with an adequate degree of slow blasting resistance, such as Guarani, to realize the benefits of seed treatment and consequent grain yield.

Experiments are generally conducted to elucidate the effect of seed treatment on the control of seed-borne inoculum, transmission, and disease development in the initial stages of crop growth, because the occurrence of other diseases does not permit evaluation of the influence of seed treatment on yield. Such an approach is satisfactory for many seed-transmitted diseases but does not adequately reflect the situation in Brazilian upland rice. The negligible incidence of leaf scald at the boot stage of growth and total absence of other diseases in both years permitted study of the integrated effect of seed treatment and cultivar resistance on leaf and panicle blast and observation of their effect on grain yield. Brazilian upland rice must be protected from the wind-borne inoculum arriving from early plantings or the inoculum from fallen, infected debris in the second or third year of planting of rice after savanna vegetation is cleared (24). Seed-borne inoculum is rarely responsible for the onset of an epidemic except in the very special situation in which planting is followed by continuous rains for a week. The fallen seed on the ground surface may

Table 4. Grain yields of untreated and fungicide treated seed plots in four rice cultivars

\begin{tabular}{|c|c|c|c|}
\hline \multirow[b]{2}{*}{ Cultivar } & \multicolumn{2}{|c|}{ Grain yield $(\mathrm{kg} / \mathrm{ha})^{\mathrm{x}}$} & \multirow{2}{*}{$\begin{array}{c}\text { Yield } \\
\text { increase } \\
\text { (kg/ha) }\end{array}$} \\
\hline & Treated $^{y}$ & Untreated & \\
\hline IAC 165 & 1,593 & 1,114 & 479 \\
\hline IAC 25 & 1,552 & 1,301 & 251 \\
\hline Guarani & 2,942 & 2,116 & $826^{z}$ \\
\hline CNA 4136 & 1,901 & 1,766 & 135 \\
\hline
\end{tabular}

${ }^{x}$ Pooled data of the 1987 and 1988 experiments.

y Seeds were treated with the fungicide pyroquilon at the rate of $4.0 \mathrm{~g}$ a.i. per $\mathrm{kg}$ of seed.

${ }^{\mathrm{z}}$ Indicates significant difference between means of fungicide-treated and untreated seed plots according to Tukey's test at the 0.05 probability level. 
germinate and the initial lesions on the seedlings may serve as a source of inoculum (1). Seed transmission of $P$. grisea to seedlings is possible when seeds are not covered by soil. Covering the seed with soil protects the seedlings against infection $(14,15)$. Seed is generally not an important source of primary inoculum in Brazilian upland rice $(24,25)$. Evaluation of improved rice cultivars with a high degree of slow blasting resistance under different disease pressures by successive planting seems to be a logical next step in continuing efforts to enhance the efficiency of fungicidal seed treatments in blast disease management.

\section{ACKNOWLEDGMENTS}

We thank F. J. P. Zimmermann for helpful suggestions and assistance in statistical analysis.

\section{LITERATURE CITED}

1. Agrawal, P. C., Mortensen, C. N., and Mathur, S. B. 1989. Blast. Pages 7-14. in: Seed-borne diseases and seed health testing. $\mathrm{CAB}$ Int. Mycol. Inst., Kew, England.

2. Ahn, S. W. 1981. The slow blasting resistance. Pages 343-370. in: Proc. Symp. Rice Resist. Blast. IRAT-GERDAT, Service de Pathologies Vegetale, Montpelier, France.

3. Anderson, A. L., Henry, B. W., and Tullis, E. C. 1947. Factors affecting infectivity, spread, and persistence of Piricularia oryzae Cav. Phytopathology 37:94-110.

4. Bandong, J. M., Nuque, F. L., Torres, C. and Crill, J. P. 1979. Leaf blast control by seed treatment with systemic fungicide. Int. Rice Res. Newsl. 4:16-17.

5. Barksdale, T. H. 1967. Spread of rice blast in small fields. Plant Dis. Rep. 51:241-243.

6. Berger, R. D. 1980. Measuring disease intensity. Pages 28-31. in: Crop loss assessment. Misc. pub. 7, Agric. Exp. Stn., University of Minnesota, St. Paul.

7. Bonmann, J. M., Estrada, B. A., and Bandong,
J. M. 1989. Leaf and neck blast resistance in tropical low land rice cultivars. Plant Dis. 73: 388-390.

8. Goto, K., Hirano, K., and Ohata, K. 1961. Susceptibility of leaf of rice to blast with reference to leaf age and position. 1. Variation of susceptibility among different leaf positions and grades of emergence of top leaf. Spec. Bull. Okayama Prefect. Agric. Exp. Stn. 58: 77-88.

9. Groth, D. E., Rush, M. C., and Lindberg, C. D. 1990. Foliar fungicides for control of rice diseases in the United States. Pages 31-52. in: Pest Management in Rice. B. T. Grayson, M. B. Green, and L. G. Copping eds. Elsevier Applied Science, London.

10. Guyer, R., and Marjudin, K. 1986. Effective control of rice blast in tropics with FONGORENE. Page 371. in: Proc. Int. Conf. Plant Prot. Tropics, 2nd. Malaysian Plant Prot. Soc., Genting Highlands, Malaysia.

11. Horsfall, J. G., and Barratt, R. W. 1945. An improved grading system for measuring plant diseases. (Abstr.) Phytopathology 35: 655.

12. Kahn, R. P., and Libby, J. L. 1958. The effect of environmental factors and plant age on the infection of rice by the blast fungus, Piricularia oryzae. Phytopathology 48:25-30.

13. Kato, H. 1974. Epidemiology of rice blast disease. Rev. Plant. Prot. Res. 7:1-20.

14. Kato, H., Ohata, K., Kauraw, L. P., and Lee, Y. H. 1988. Fungal diseases of rice seed. Pages 151-162 in: Rice Seed Health. Int. Rice Res. Inst., Manila, Philippines.

15. Kingsolver, C. H., Barksdale, T. H., and Marchetti, M. A. 1984. Rice blast epidemiology. Bull. 853, Agric. Exp. Stn., The Pennsylvania State University, University Park.

16. Koh, Y. J., Hwang, B. K., and Chung, H. S. 1987. Adult plant resistance of rice to leaf blast. Phytopathology 77: 232-236.

17. Loehken, A. 1990. The benefits of seed/early season fungicide application for the management of rice blast (Pyricularia oryzae) Pages 71-86 in: Pest Management in Rice. B. T. Grayson, M. B. Green, and L. G. Cooping, eds. Elsevier Applied Science, London.

18. Marchetti, M. A., Rush, M. C., and Hunter, W.
E. 1976. Current status of rice blast in the Southern United States. Plant Dis. Rep. 60: 721-725.

19. Marchetti, M. A., and Xinghua, L. 1986. Screening techniques to identify slow blasting rice lines. Pages 317-326 in: Progress in Upland Rice Research. F. J. Shilder and C. V Mendoza, eds. Int. Rice Res. Inst., Manila, Philippines.

20. Nakamura, M. 1986. Coratop Fongorene (common name: pyroquilon): A new systemic blast fungicide in rice. Jpn. Pestic. Inf. 48:2730 .

21. Ou, S. H. 1985. Rice Diseases. 2nd ed. Commonw. Mycol. Inst., Kew, England.

22. Prabhu, A. S., Faria, J. C., and Carvalho, J. R. P. 1985. Effect of blast, dry matter production, grain yield and yield components in upland rice. (In Portuguese with English summary) Pesqui. Agropecu. Bras. 21:495-550.

23. Prabhu, A. S., Faria, J. C., and Zimmermann, F. J. P. 1989. Comparative yield loss estimates due to blast in some upland rice cultivars. Fitopat. Bras. 14:227-232.

24. Prabhu, A. S., and Filippi, M. C. 1993. Seed treatment with pyroquilon for the control of leaf blast in Brazilian upland rice. Int. J. Pest Manage. 39:347-353.

25. Prabhu, A. S., and Morais, O. P. 1986. Rice blast management in upland rice in Brazil. Pages 382-394 in: Progress in Upland Rice Research. F. J. Shilder and C. V. Mendoza, eds. Int. Rice Res. Inst., Manila, Philippines.

26. Roumen, E. C., Bonman, J. M., and Parlevliet, J. E. 1992. Leaf age related partial resistance to Pyricularia oryzae in tropical lowland rice cultivars as measured by the number of sporulating lesions. Phytopathology 82:1414-1417.

27. Snedecor, G. W., and Cochran, W. G. 1978 Statistical Methods. 6th ed. Iowa State University Press, Ames.

28. Van der Plank, J. E. 1963. Plant Diseases: Epidemics and Control. Academic, New York.

29. Williams, R. J., Marjudin, K., and Guyer, R. 1985. Rice blast control by seed treatment with pyroquilon. (Abstr.) Phytopathology 75: 1383. 